\title{
Fibromialgia: O Desafio do Diagnóstico Correto
}

( tema fibromialgia sempre esteve envolto em controvérsias e polêmicas. Mesmo o estabelecimento de seu conceito e a validade do uso do termo "fibromialgia" como diagnóstico específico têm sido motivo de debate na literatura até nos dias de hoje.

Acredito que essa seja uma questão já superada. Os pacientes têm um quadro clínico uniforme e quando agrupados sob a denominação de "síndrome da fibromialgia" puderam ser estudados através do método científico, obtendo-se assim grandes avanços no entendimento, não só da sua fisiopatologia, como também de abordagens a serem implantadas.

A questão do diagnóstico, porém, ainda deve ser mais explorada. A utilização dos "Critérios de Classificação para Fibromialgia” do Colégio Americano de Reumatologia foi um grande avanço em termos de inclusão em estudos científicos. Mas para uso individual, com fins diagnósticos, ainda deixa muito a desejar.

O mesmo pode ser dito em relação aos "pontos dolorosos" (tender points) que, embora tenham sua utilidade, não parecem ser determinantes para o diagnóstico de fibromialgia. O mais provável é que, na hipótese diagnóstica, tenhamos que considerar o conjunto total de sinais e sintomas, além de levarmos em conta a presença das afecções satélites. É essencial termos em mente a teoria fisiopatológica atualmente aceita como mais provável, ou seja, que estamos diante de uma disfunção no processamento da dor. Portanto, estaríamos diante de uma síndrome de amplificação dolorosa. Provavelmente, essa explicação não contemple todas as características dessa síndrome, mas é um ponto de partida importante para que a compreendamos.

As dificuldades diagnósticas aumentam quando se trata de colegas de áreas básicas ou de especialidades que não têm tradição em pesquisa da fibromialgia. No início da história da fibromialgia observava-se escassez de diagnósticos. Atualmente, temos o contrário, uma abundância de diagnósticos, com muitos falsos positivos. O impacto dessa dificuldade extrapola o cuidado do paciente e passa a afetar o relacionamento de médicos e pacientes com a sociedade. Um exemplo é a questão trabalhista que envolve essa síndrome.
Em um artigo nessa edição, Milton Helfestein Jr, da Universidade Federal de São Paulo (UNIFESP), apresenta o caso de uma paciente com diferentes diagnósticos de lesões musculoesqueléticas e dor difusa, sugerindo que o diagnóstico correto seria fibromialgia. Aponta vários problemas nos diagnósticos prévios e salienta que o caso não é de doença ocupacional, discutindo também a necessidade do afastamento do trabalho. Comenta com propriedade erros de interpretação dos exames subsidiários e enfatiza a necessidade da correlação com achados clínicos.

$\mathrm{Na}$ questão da relação da fibromialgia com o trabalho, parece claro e já bem estabelecido que essa síndrome não seja ocupacional, embora possa ser desencadeada pelo trabalho, principalmente nos casos em que um ambiente inadequado se associa à insatisfação pessoal com a atividade.

Afastar ou não o paciente de sua atividade profissional é um outro assunto polêmico. O objetivo de todo médico, e em especial do reumatologista, é manter seu paciente com uma boa qualidade de vida. Dentro desse conceito, a independência pessoal bem como a inserção produtiva na sociedade devem ser mantidas. Acredito que o afastamento do trabalho nos casos de fibromialgia deva ser uma medida extrema, pois contraria a expectativa de uma saúde adequada. Entendo que, em determinados períodos, quando a intensidade dos sintomas for grande ou mesmo quando se apresentarem co-morbidades, essa conduta possa ser considerada.

Em suma, é fundamental que se aperfeiçoe a avaliação dos pacientes tanto em relação ao diagnóstico quanto ao impacto das síndromes musculoesqueléticas. O diagnóstico deve ser baseado na observação clínica com auxílio de exames subsidiários e não exclusivamente nos seus resultados. Infelizmente, esse erro é cometido com freqüência, especialmente no meio pericial. Critérios e instrumentos de avaliação de impacto devem ser aperfeiçoados e difundidos entre os profissionais da área trabalhista e pericial.

José EdUARdo MARTINEZ Titular do Departamento de Medicina da Pontifícia Universidade Católica de São Paulo (PUC-SP) 